\title{
Electronic Word of Mouth as Business Anticipation During the Pandemic Covid-19
}

\author{
Novi Andayani Praptiningsih ${ }^{1}$, Dede Hasanudin ${ }^{2}$, Heni Ani Nuraeni ${ }^{3}$ \\ ${ }^{1}$ Communication Department, Social and Political Science Faculty, University of Muhammadiyah Prof. Dr. HAMKA \\ (UHAMKA) Jakarta, Indonesia 12520 \\ ${ }^{2,3}$ Indonesian Language and Arts Education Department, Education Science Faculty, University of Muhammadiyah Prof. \\ Dr. HAMKA (UHAMKA) Jakarta, Indonesia 12520
}

corresponding author : novi.ap@uhamka.ac.id

\begin{abstract}
This study discusses one of the culinary business, especially beverages that are popular is Thai Tea. Competition in type of beverage business is very tight plus a brand that comes up because of the opportunity that exist. This study aims to determine the implication of e-WoM that occurs in social media Instagram on the formation for positive image of Thai Tea. The research method used is qualitative through data collection techniques such as in-depth interviews and observation, using Interactive Model. The results showed that communication activities electronic word of mouth through social media is very strong by using the features provided by Instagram and the buyer's experience is satisfactory, especially in covid-19 pandemic era.
\end{abstract}

Keywords: electronic, business, word of mouth, anticipation, covid-19.

\section{INTRODUCTION}

Many companies create official Instagram accounts for the products they sell and use Instagram Social Media as a field to reap benefits in terms of image and reputation, and also attract more consumers. Through the complete features found on Instagram, the opinions expressed by Instagram users through comments or reviews of products and brands can be an advantage or a disadvantage for these products and brands. The development of new media cannot be separated from the emergence of the Internet and the World Wide Web due to the globalization of information technology. The emergence of new media has contributed to changing the communication patterns of society. According to Jefkins [1], image is an impression obtained in accordance with knowledge and understanding of facts. Incorrect or incomplete information will result in the image being imperfect or inaccurate. In this fast paced world, word of mouth is growing even more rapidly which is now reaching the internet and giving birth to eWOM. eWOM is communication advice in the form of negative or positive suggestions that occur on the Internet [2]. Every consumer who has consumed a product will provide his own assessment for the product, and cannot be influenced because it comes from himself, after that if the consumer is satisfied or not satisfied with the consumption of the product, the consumer will tell the product review to other people have accounts on social media, email, blogs, or websites that have previously been created. [3]

Dum Dum Thai Tea brand is one of the products that carries out e-WOM activities to increase public awareness of Dum Dum. The form of Electronic Word of 
Mouth used by Dum Dum is the social media Facebook and Instagram, because Facebook and Instagram are one of the communication media that involves the account owner, Dum Dum, and his followers. In Dum Dum's social media, there is information about promos, information on the opening of new shops, information on the variety of flavors served by Dum Dum. The purpose of this study was to identify and analyze electronic word of mouth as business anticipation during the Covid-19 pandemic.

The advancement of internet technology has made the position of WoM which used to be relied upon by many to begin to shift. Today's consumers are starting to rely more on $\mathrm{e}-\mathrm{WoM}$ in the process of finding information before buying a product. Thus, the strategy setting of the remarketing practitioner is again related to who the target consumer is because not everyone can be exposed to the WoM and e-WoM strategies. If the target is wrong, then communication from the company to consumers will be ineffective and will have an impact on the low consumer buying interest [4].

Before the emergence of e-WoM, word of mouth (WoM) communication was first known. Word of mouh communication refers to the exchange of comments, thoughts or ideas between two or more consumers, neither of which is a source of marketing. Even in the world of education, prospective students looking for scholarship references or further study abroad also consider word of mouth that goes beyond advertising. Word of mouth Euro Management affects the interest of students to continue their studies in Europe, especially Germany [5]. Four main dimensions identified to measure e-WoM are: first, intensity (activity, frequency, dispersion. Second, positive valence (praise). Third, negative valence. Fourth, content [6]. According to Babin, et all [7] that the indicators of Word Of Mouth Communication are: first, discussing someone's willingness to talk about positive things about product quality to others. Consumers expect maximum satisfaction and have interesting material to talk about with people. Goldsmith and Horowitz [8], reveal in reflecting on feeling pleasure and satisfaction from consumers, it will be directly proportional to a positive image view for the product or brand. Electronic word of mouh communication refers to the exchange of comments, thoughts or ideas between two or more consumers, neither of which is a source of marketing.

Eunha, J. and Soocheong, S.J [9] focused on the positive view of consumers on the experience of a restaurant through e-WOM which reviews delicious food and drinks at the restaurant. They reflect the positive dimensions of electronic word of mouth through three dimensions, namely: First, Concern for Others. One's concern for others, for example preventing others from buying a bad product or service. [2]. One's concern for others is a very important motive in the food and beverage industry, because the products or services produced by these brands rely on customers' WOM or eWOM to attract other consumers. Second, Express Positive Feelings. Expressing positive feelings is triggered when consumers have consumed a product. The positive experience of a customer will contribute positive information to others. [2] until it can be ascertained, positive information will be obtained if they get satisfaction with the product. Third, concern for others. The difference is in the object, customers will be motivated to be involved in eWOM activities to give a reward to the company, which is to provide a positive experience when they feel the product or brand. [2]. Chu, et all [10] concluded that Friends' Circle on WeChat has helped make e-WoM more accessible. Research on consumer engagement and eWOM. The results showed that the need for self-improvement positively influenced the involvement of Chinese tourists [10]. The results of research by Torlak, et al. [11], young Turkish consumers consider the reviews obtained from electronic word of mouth channels and use these reviews in forming brand image perception.

\section{METHOD}

Research Design. This study uses a qualitative approach. Methodology is defined as the entire design of the investigation that links the main elements of data interpretation based on the theoretical framework used. While the method, more explains how or work in data collection and data analysis.

Participant. Resource persons as participants are appropriate people to be involved in research activities are able to provide information related to research. Several internal and external sources in this study: (1) Dum Dum Instagram admin, is someone who manages mobility on Instagram social media, Dum Dum Instagram admin also has the power to reply to comments, reply to Direct Messages from followers, upload photos every day and also Latest news updates from Dum Dum. (2) Followers of Dum Dum Thai Drinks on Instagram The consumers of Thai Tea Dum Dum who will be studied are consumers who are followers of Thai Tea Dum Dum on Instagram social media. Because the followers of Thai Tea Dum Dum have an effect on improving the image of Dum Dum products. The number of informants from Dum Dum's followers on Instagram is more than one person. (3) Food Blogger / Influencer. Food Blogger has a lot of experience and knowledge about Instagram in the advancement of the food and beverage industry via social media.

Data collection technique. In collecting primary data, the writer uses in-depth interview technique. Meanwhile, secondary data is research data which contains information and theories used to support research. The author will collect data from company data, 
company documents, library books, articles, magazines, and the internet related to Thai Tea Dum Dum. Researchers also use document / literature studies which are interpreted as an effort to obtain data and information in the form of written notes or stored pictures related to the problem under study.

Data analysis technique. The data analysis technique used is the interactive model of Miles-Huberman [12] where data activities are carried out continuously until the data is saturated.

\section{RESULT AND DISCUSSION}

Dum Dum Thai Tea is one of the Thai tea franchise companies with the largest network in Indonesia. The branding carried out by Dum Dum Thai Tea is quite good by targeting middle to upper class consumers and including beverage franchise companies that introduce Thai tea products to Indonesian consumers. Dum Dum thai tea has spread in almost all malls in Jakarta and even throughout Indonesia which is registered on the official Instagram @dumdumthaidrinks. Currently, Dum Dum Thai Tea has branches in 32 cities in Indonesia.

From several Dum Dum franchise shops spread across Indonesia, researchers are interested in researching one of the Dum Dum franchises located in the Bumi Serpong Damai area or commonly known as BSD, which is located in the Maxley Hotel building. Researchers are interested in the Maxley franchise because of its strategic location, it has challenges because it is not in a shopping place, and has the most active social media Instagram compared to other Dum Dum Thai Tea franchise social media accounts. Dum Dum Thai Tea, Maxley BSD branch started sales on November 17, 2017 in a 4m x 5m plot in the front yard of Hotel Maxley. The products provided by Dum Dum Thai Tea have two types, namely drinks with a mixture of milk and those that do not use milk, for menus with a mixture of milk including Original Thai Tea, Geen Tea Thai Tea, Milo Thai Coffee. Meanwhile, drinks that don't use milk include Thai Black Tea, Thai Black Coffee, Milo Coffee, Thai Lime Tea. All drinks are available in cold and hot form.

In this life, humans are the most perfect creatures from other living things. Humans are social creatures who cannot be far from each other. Interpersonal communication gives rise to a communication practice called word of mouth. In a world that demands fast-paced humans, word of mouth is growing even more rapidly which is now reaching the electronic world to the internet and giving birth to eWOM. eWOM is a communication suggestion in the form of negative or positive suggestions that occur on the Internet [2]. From the results of research conducted with four sources with different backgrounds, the researcher obtained research findings that the role of netizens or Instagram users is very important in building the good image desired by business people for the progress of their business. Through the various features provided by Instagram, Instagram users can do various things that are beneficial to themselves and others. Recommending goods, food or drinks, to services is often done on social media to help others and not a few have reasons to help others avoid bad experiences they have experienced.

The following are the results found by researchers with a research focus on eight dimensions in electronic word of mouth: First, Concern for Other Concumers, consisting of: (1) Recommendations for Others through Instagram. Instagram is no longer taboo for social media users in Indonesia, especially teenagers. The amount of information passed on by users or netizens can also go viral and can have a negative or positive impact on the information itself. As experienced by the Dum Dum Thai tea product which was once viral and booming in the local market to penetrate the Thai and Malaysian markets, it turns out that this product is an Indonesian product. The power of viral and also recommendations from people around can bring them to meet this product Dum Dum Thai Drinks. Dum Dum Thai Drinks for them is a pioneer Thai tea drink in Indonesia which is also very popular because of the fragrant aroma of using black tea. (2) The role of followers' comments on Instagram. Dum Dum Thai Drinks products have an official account in each of its branches. The main account of Dum Dum Thai Drinks itself is@dumdumthaidrinks, then there are branch accounts such as @ dumdumthaidrinks.MaxleyBSD for Dum Dum's Instagram account at Maxley BSD, @ dumdumthaidrinks.Isa for Dum Dum's Instagram account at Lotte Shoping Avenue, @ dumdumthaidrinks.bali for the Dum Dum Instagram account in Bali, and many dozens of others. In social media, Instagram has a feature called "comments" which functions to provide comments on content uploaded by other Instagram users. Comments on Instagram can also be a means of interacting with account followers, besides that comments also have a good role for a brand or product. (3) Which Affects Information Dissemination of Dum Dum Thai Drinks. Researchers examined Instagram @dumdumthaidrinks, there are two photos uploaded every day. Dum Dum Thai Drinks Instagram content contains information about Thai Tea Dum Dum products such as the location of a new shop, photos of Dum Dum consumers, and also posters of the announcement of the competition organized by Dum Dum. Social media content and appearance influence the image of Dum Dum Thai Drinks. Some of the content also invites communication in the comments column by followers. The number of comments about Instagram content uploaded and communication that occurs on other Instagram features. The more attractive the Instagram view of a product is, it will make other Instagram users want to explore more about the products being sold, especially the content that is served is very interesting and informative. 
Second, Express Positive Feelings, consisting of: (1) Talking About Dum Dum Thai Drinks. Dum Dum Thai Drinks has an Instagram account with a total of more than 14,900 followers. There are more than a hundred photos of his followers who use the tag feature or tag Dum Dum on Instagram. That means more than a hundred Instagram users have uploaded photos of Dum Dum products. More than a hundred people who tagged Dum Dum and indirectly talked about Dum Dum on social media. Many comments circulating about Dum Dum. Dum Dum lovers have their own network of friends, so when he has good information, they will share that information with others. (2) Instagram features used for information dissemination. In expressing themselves after consuming Dum Dum Thai Drinks and getting the expectations they want, Instagram users use several Instagram features that are used, Instagram has a variety of features that can make it easier for users to enjoy content that is spread in cyberspace. Dum Dum Thai Drinks consumers who follow Dum Dum on Instagram social media often do word of mouth activities on Instagram social media using the following features: a. Instastory. Consumers can share a visual image of Dum Dum Thai Drinks and be watched or seen by followers of that Instagram user and will be repeated continuously. b. Like. Instagram users, especially followers of @dumdumthaidrinks or Dum Dum branches, for example @ dumdumthaidrinksmaxley.bsd users can "like" or "like" every upload of content served by Dum Dum. If the likes that are collected or obtained by the Dum Dum Instagram account are very large and frequent, it is not impossible for these photos, videos, or content to appear in the explore line. Explore is a line of photos that are currently popular on Instagram for 24 hours. With the photos or content that appear in the explore section, more and more will see photos or videos about Dum Dum. c. Mention. The mention feature is a feature where Instagram users can invite one person to more users to see the same link. This activity is one of the activities to communicate through media on Instagram which is very unique. Because the dissemination of information is made easier by simply writing the names of other users, then other users will automatically be called in the notification or notification section on Instagram. This activity is one that Dum Dum consumers do to disseminate information about dum dum. You can see that some of the mentioned features are in several posts for Dum Dum Thai Drinks. This means that there are also information dissemination activities about Dum Dum by word of mouth via electronics. d. Tag. The "Tag" feature is a feature where Instagram users can tag an account in a photo post so that other users can find out what account is in the photo. As Dum Dum lovers do, users post a photo holding Dum Dum, then mark the official dum dum account where they bought it, tagging the photo with the account @dumdumthaidrinksmaxleybsd or@dumdumthaidrinks so that other users who see the photo know the Dum Dum Thai Drinks account.

Third, Helping The Company, which in essence found "How to Build a Positive Community View of Dum Dum". Customer satisfaction is a pleasure for the company. Many things will be obtained after customer satisfaction is achieved, such as repeated purchases, adding customers, to getting more benefits from customers, namely that the customer will become a living promotional media. The customer will spread information about the product or brand that he likes as a recommendation to the closest people to spread it in the community. Satisfied customers will spread positive information about the product. The same thing is done by Instagram users who have participated to improve Dum Dum's image. Dum Dum Thai Drinks also maintains the content that will be uploaded to the public, because the content and appearance of a product or brand will affect the quality and image of the product or brand.

\section{CONCLUSIONS}

The role of followers is very important for a brand that uses social media, because each of their comments on Instagram can also be a means of interaction with other account followers (Concern for Other Concumers). By getting things according to their expectations, without any instructions and encouragement from Dum Dum to promote the product. Dum Dum connoisseurs automatically upload photos and descriptions that are good or positive about Dum Dum. It seems that there is satisfaction from consumers who buy Dum Dum so they share their experiences on Instagram social media which will be seen by their followers on social media (Express Positive Feelings).

Satisfied customers will spread positive information about the product. Similar to what has been done by Instagram users who have participated to raise Dum Dum's image, by using some frequently used Instagram features such as tags and mentions. Tag and mention activities also occur in the Instastory feature which can upload photos and videos that have been seen by many people repeatedly for twenty-four hours (Helping The Company).

\section{REFERENCES}

[1] Jefkins, Frank. 2003. Public Relations. Jakarta: Erlangga

[2] Hennig-Thurau, T., Gwinner, K.P., Walsh, G., Gremle, D.D. (2004). Electronic word-ofmouth via consumer-opinion platforms: What motivates consumers to articulate themselves on the Internet Journal of Interactive Marketing, 18, 38-52. 
[3] Lee, J ,Park,D.H \& Han, I (2008). The effect of negative Online Consumer Reviews on Product Attitude: An Information Processing View. Electronic Commerce Research and Applications, 7(3), 341-351

[4] Andrew, Tjenghar Widjaja,. (2016). Pengaruh word of mouth dan electronic word of mouth terhadap purchase intention: sebuah studi kasus mengenai perilaku konsumen terhadap jasa ojek online Gojek. Jurnal Bisnis dan Manajemen Vol. 53 No. 12, Desember 2016, 241-253.

[5] Praptiningsih, Novi Andayani. (2019) The Effect of Word of Mouth on Student Interest Study to Germany Through Euro Management. Journal Perspektif Komunikasi Vol. 3 No. 1 2019, 23-29. ISSN. 2549-0613. https://jurnal.umj.ac.id/index.php/perspektif/articl e/view/4711/3277

[6] Goyette et al,. (2010) e-WOM Scale: Word-ofMouth Measurement Scale for e-Services Context. Canadian Journal of Administrative Sciences. Vol.27, 2010. 5-23.

[7] Babin, Barry J., Yong-Ki Lee, Eun-Ju Kim, Mitch Griffin. (2005). Modeling Consumer Satisfication And Word Of Mouth Communication: Restorant Petronage Korea. Journal of Servive Marketing Vol. 19 No. 3, 133- 139.
[8] Goldsmith, R.E \& D. Horowitz. (2006). Measuring motivations for online opinion seeking. Journal of Interactive Advertising, 6(2), 3-14.

[9] Jeong, Eunha., Jang, Soo Cheong. (2011). Restaurant Experiences Triggering Positives Electronic of Mouth Motivation. International Journal of Hospitality management. 30 (2011), 356-366.

[10] Chu, Shu Chuan, He-Hui Lien, Yang Cao. (2018) Electronic of word mouth (eWOM) on WeChat: examining the influence of sense of belonging, need for self-enhancement, and consumer engangement on Chinese travellers' eWOM. International Journal of Advertising Vol. 38/2019, Issue $1, \quad$ p. $26-49$. https://doi.org/10.1080/02650487.2018.1470917

[11] Torlak, Omer; Behcet Yalin Ozkara; Muhammet Ali Tiltay; Hakan Cengiz; Mehmet Fatih Dulger.(2014). The Effect of Electronic Word of Mouth on Brand Image and Purchase Intention: An Application Concerning Cell Phone Brands for Youth Consumers in Turkey. Journal of Marketing Development and Competitiveness vol. 8.

[12] Miles, M.B., \& Huberman, A.M. (2012). Qualitative Data Analysis : an Expanded. CA : Sage Publications 